\title{
O PRINCÍPIO DO EXERCÍCIO PROFISSIONAL: na formação da identidade docente
}

Letícia Mendonça Lopes Ribeiro Ednaceli Abreu Damasceno ${ }^{*}$

\section{INTRODUÇÃO}

A presente pesquisa objetivou identificar aspectos marcantes do princípio do exercício profissional vivenciado por professores iniciantes, considerando a importância desta fase na formação da identidade docente, bem como a relevância de suas experiências de socialização profissional nos primeiros momentos do magistério.

Nesse cenário, é preciso reconhecer que a aprendizagem do trabalho docente antecede e é parte do percurso de escolarização, uma vez que muitos docentes certamente passaram um longo tempo, durante sua juventude, no ambiente da sala de aula. Logo, ao longo de sua própria escolarização - e, especialmente, durante sua formação teórica para o exercício do magistério - o futuro docente recebe orientações e consolida vivências que o guarnecerão de conhecimentos teóricos e técnicos que os habilitarão a lecionar. Dessa forma, o empenho em destacar o início da trajetória do professor, no exercício docente, é enfatizado por se atribuir que esta é a fase na qual os professores iniciantes vivenciam um momento crucial em suas vidas profissionais. Tal momento é determinado por Eddy (1971 apud TARDIF, 2002) caracteriza como "rito de passagem", no qual o novo professor sai da posição de estudante para assumir sua condição profissional.

É nesse rito de passagem, concebido no princípio da trajetória docente, que o professor vivencia algumas de suas oportunidades mais decisivas para a construção de sua própria identidade profissional. Nesse âmbito, é de suma importância compreender as identidades profissionais como um resultado, simultaneamente, "estável e provisório, individual e coletivo, subjetivo e objetivo, biográfico e estrutural, dos diversos processos de socialização que, conjuntamente, constroem os indivíduos e definem as instituições” (DUBAR, 2005, p.136).

\footnotetext{
${ }^{(*}$ Letícia Mendonça Lopes Ribeiro. Centro de Educação, Letras e Artes da Universidade Federal do Acre. Mestre em Educação pela Universidade Federal do Acre. Professora dos cursos de licenciatura vinculados ao Centro de Educação, Letras e Artes da Universidade Federal do Acre. E-mail: leticiamendonca@yahoo.com.br;

Ednacelí Abreu Damasceno. Centro de Educação, Letras e Artes da Universidade Federal do Acre. Doutora em Educação pela Universidade Federal de Minas Gerais. Vice-coordenadora e professora do Programa de Pós-Graduação em Educação da Universidade Federal do Acre. E-mail: ednaceli@yahoo.com.br.
} 
Com base nos pressupostos teóricos, parcialmente apresentados, deu-se a construção metodológica deste estudo. Trata-se de uma pesquisa qualitativa por comportar um universo de significados, motivos, valores e atitudes que possuem um vínculo com os processos - vivenciados pelos professores iniciantes - os quais não podem ser reduzidos à operacionalização de variáveis (MINAYO, 2002).

Como principal instrumento de pesquisa, optou-se pela entrevista semiestruturada, a qual combina perguntas abertas e fechadas, nas quais os entrevistados tiveram a possibilidade de discorrer sobre o tema proposto (MINAYO, 2013). Estas foram aplicadas a cinco professores que estavam, na época da coleta de dados, há menos de três anos em exercício profissional. Tal período de atividade docente foi delimitado de acordo com os estudos propostos por Huberman (1992), o qual determina que este é um período crucial na iniciação do docente. Segundo este autor, até o terceiro ano de exercício profissional, o professor vivencia simultaneamente os períodos de sobrevivência (marcado por dúvidas, frustrações e inseguranças) e de descoberta (marcado pelo orgulho, familiaridade e satisfação profissional).

Outras características importantes destes sujeitos são a formação inicial (licenciados em pedagogia em uma mesma universidade) e todos lecionaram como unidocentes em escolas de ensino fundamental, sendo que quatro deles atuaram em classes dos anos inicias do ensino fundamental ( $1^{\circ}$ ao $5^{\circ}$ ano). É importante entender a condição de unidocente, (também reconhecido como professor polivalente) na qual um mesmo professor trabalha todas as disciplinas com a mesma turma, responsabilizando-se pelo ensino não apenas de todos os conteúdos, mas também da integração da criança no ambiente escolar (LIMA, 2007).

Os sujeitos foram nomeados com nomes de flores, estando caracterizados como Alfazema, Rosa, Margarida, Dália e Lírio - sendo, este último sujeito, o único do sexo masculino. Tais caracterizações procuraram manter o anonimato dos sujeitos - como bem estabeleceu o Termo de Consentimento Livre e Esclarecido (TCLE) dos participantes que, mediante ciência e autorização por eles expressa, antecedeu da entrevista cedida por cada um deles, individualmente.

Diante desse cenário, é importante ressaltar como este texto está estruturado: após a presente Introdução, apresenta-se a Fundamentação teórica que corrobora a compreensão do tema trabalhado; em seguida, expõem-se os Resultados e a Discussão advindos da coleta de dados; por fim, exibem-se as Considerações Finais, as quais permitiram uma breve síntese do trabalho ora desenvolvido, bem como discute dos achados tidos, tendo como base as questões centrais que mobilizaram e orientaram o percurso investigativo da pesquisa. 


\section{FUNDAMENTAÇÃO TEÓRICA}

Como parte da compreensão dos fundamentos teóricos que auxiliam no entendimento da trajetória docente, abordada na pesquisa, é essencial caracterizar as expressões "professores iniciantes" e "socialização profissional" - contextualizadas ao conhecimento sobre "identidade docente".

Para Marcelo García (1999), o professor iniciante - o qual pode ser nomeado também como principiante ou debutante - é aquele que enfrenta um período de iniciação à docência. Tal período pode ser entendido como uma das fases da trajetória docente, a qual é marcada pelo vínculo entre a formação inicial e o desenvolvimento profissional na carreira. Dentre essas diferentes fases, a iniciação à docência é apenas uma; outras fases são vivenciadas pelo professor até alcançar a consolidação de sua experiência.

Já os estudos de Michael Huberman (1992) fazem indicações sobre o desenvolvimento profissional docente com estimativas em anos. A entrada na carreira, por exemplo, é assinalada como a primeira fase da vivência do professor em situação de sala de aula, sendo estimada entre os dois a três primeiros anos de exercício docente. É nesse período, delimitado especificamente entre o segundo e terceiro ano de exercício do magistério, que os iniciante costumam vivenciar momentos simultâneos de sobrevivência (instabilidade pessoal e profissional, com dificuldades referentes ao controle da indisciplina e com a prática de ensino) e descoberta. (o entusiasmo inicial que ameniza as dificuldades, a sensação confortante em ter a sua sala de aula, os seus alunos, o seu programa e pertencer a um determinado corpo profissional). Entretanto, Huberman atenta que há, ainda, professores iniciantes que apresentam outros perfis neste mesmo momento da trajetória docente, caracterizados como:

A indiferença ou quanto-pior-melhor (aqueles que escolhem a profissão a contragosto ou provisoriamente), a serenidade (aqueles que têm já muita experiência), a frustração (aqueles que se apresentam com um caderno de encargos ingrato ou inadequado, tendo-o em atenção à formação ou à motivação iniciais) (HUBERMAN, 1992, p.39).

Após a fase de entrada na carreira, Huberman elenca outras fases. São essas: a fase de estabilização, a fase da diversificação, a fase do pôr-se em questão, a fase da serenidade e distanciamento afetivo associada à fase do conservadorismo e lamentações e, por fim, a fase de desinvestimento. Nesse contexto, ao se pensar em toda uma trajetória de exercício profissional, é importante vislumbrar também o processo de socialização profissional - e sua importância na formação da identidade docente. 
De acordo com Tardif e Raymond (2000), a socialização profissional pode ser entendida como uma trajetória fundamental pelo qual as identidades dos profissionais são estabelecidas em processos complexos. Tais processos estão em permanente construção e se associam a situações, percursos, tarefas e perspectivas compartilhadas consigo (o próprio profissional) e com seus pares (colegas de trabalho). É nesse cenário que se "estruturam mundos do trabalho e que se definem os indivíduos por seu trabalho" (DUBAR, 2012, p. 358).

Nesse cenário, é preciso entender que a identidade do trabalhador (na educação ou em outra profissão) pode sofrer modificações através do trabalho. Na visão de Dubar (1992), o trabalho não é transforma exclusivamente um objeto ou situação em uma outra coisa, como também transforma o próprio agente do trabalho, levando à construção da identidade profissional de um indivíduo.

É nessa trajetória, de construção da identidade com o magistério, que o professor consegue se perceber como profissional desta classe e se posiciona como tal. Assim, diante da compreensão dos aspectos centrais que norteiam o entendimento teórico do assunto, apresenta-se a seguir a coleta e análise de dados da pesquisa, a qual enfatiza as vivências iniciais dos sujeitos de pesquisa no inicio do exercício docente.

\section{RESULTADOS E DISCUSSÃO: OS SUJEITOS DA PESQUISA E SUAS VIVÊNCIAS NO PRINCÍPIO DA DOCÊNCIA}

Ao serem motivados a indicar os detalhes sobre as suas primeiras experiências como professores regentes, os entrevistados tiveram autonomia em relatar as vivências julgadas por eles como mais marcantes em todas as classes e/ou escolas em que lecionaram no início da regência (três primeiros anos de exercício profissional).

Em uma delimitação mais específica, os sujeitos de pesquisa foram estimulados a caracterizar os aspectos mais importantes que caracterizavam suas primeiras classes no ensino fundamental. Nesse contexto, duas entrevistadas, Rosa e Dália, relatam aspectos semelhantes na caracterização das classes em que iniciaram suas experiências. Ambas iniciaram sua experiência como regentes de classe em turmas do primeiro ano do ensino fundamental, em escolas da rede estadual. Outra característica coincidente é que, mesmo conscientes da inexperiência profissional por elas carregada, ambas tiveram, como primeiras classes, turmas muito desafiadoras.

Aí eu peguei a turminha assim, porque era uma turma maior, tinha uns 32 alunos nessa turma.

Então, dividiram essa turma, aí a professora que já era antiga na escola, ficou com os alunos mais avançados, e eu peguei os alunos que estavam precisando de apoio. Assim... eu fiquei 
com 17 alunos. Dos 17 alunos que eu tinha, nenhum era alfabético; então assim, a maioria era pré-silábico. (Rosa)

Me jogaram, me colocaram lá, naquela escola, né? [...] Cheguei lá, me colocaram dar aula na turma do primeiro aninho, é alfabetização, né? E eu, no primeiro ano, não tinha nenhuma experiência. E tinha uns 30, 32 ou 35 alunos... E só eu. E já tinha passado três professoras lá, só no início do ano. [...] Os alunos eram muito... Era tudo muito difícil, muito mesmo. Não sabiam nada! [...] Mas aí... Até que a diretora pegou, me trocou... Acho que eu fiquei uns dois meses, no máximo. [...] Eu já estava... eu estava pra desistir da profissão. Sinceramente, passou pela minha cabeça de desistir do concurso, eu disse: “Isso aqui não é pra mim, não". (Dália)

Esses relatos trazem claramente a noção de que, apesar de inexperientes, muitos ingressam como regentes em turmas mais desafiadoras (NÓVOA, 1991), sendo que o ideal seria exatamente o contrário: a escola deveria se preparar para receber o novo professor e o amparar em suas primeiras experiências.

Em um sentido semelhante, mas em uma situação diversa das demais entrevistadas que lecionaram inicialmente na rede pública, tem-se a experiência de Lírio. Seus relatos mostram o quão desafiadora é a primeira sala de aula em uma classe multisseriada. No caso deste sujeito, o desafio também se estabeleceu devido à falta de infraestrutura da comunidade, da escola e, especialmente, da sala de aula. Em princípio, a classe onde Lírio lecionou não contava com mobiliário adequado, possuía pouquíssimo material didático e seus alunos tinham idades e níveis de aprendizado muito distintos.

$\mathrm{Na}$ questão das disciplinas em si, havia muita carência de material. O material a gente conseguiu a maior parte com a Secretaria de Educação, graças à minha ida lá, pra lá. Porque como eu estava tendo suporte da Secretaria, eles começaram a avaliar o que é que estava pendente. Aí trouxeram, né, aproveitaram a situação, que eu saí com um caminhão carregado de cadeiras e mesas escolares também, porque lá não tinha. Antes, era madeira serrada, colocada uma mais alta assim, outra mais baixa... É, difícil... esse mobiliário eu trouxe, trouxe merenda também, né? E foi daí que a gente foi se adequando à situação. [...] Dos alunos, tinha uns 20, mas nem todos iam. A faixa etária, a maior parte era entre 11 e 18, 20 anos, ela [merendeira da escola] era a mais velha da turma. [...] Todo o percurso de vida escolar deles é complicado, né? É dificultoso, e muitos deles não desenvolveram, tem muita dificuldade... (Lírio).

Pelos relatos de Lírio e pelos trabalhos que discutem as vivências das escolas e classes multisseriadas, reconhece-se que, em turmas, como estas, o frequente apontamento sobre as péssimas condições estruturais de algumas escolas públicas se acentua, acrescentado às condições precárias de trabalho dos professores do campo, coerentes com as próprias condições precárias da produção da vida no campo brasileiro (JANATA e ANHAIA, 2015). Lírio também relata suas 
angústias nos primeiros dias em que chegou à comunidade rural, em uma nova realidade, tão distinta das situações frequentes do meio urbano - local que ele esperava trabalhar quando formado, como a maioria dos egressos dos cursos de formação de professores (TERUYA et al, 2013).

Eu não conhecia ninguém de lá, da comunidade, não conhecia ninguém. Eu não sabia onde eu ia ficar. Fui de bagagem e tudo, pronto para ficar lá o tempo que fosse. A princípio, ficaria na escola, só que a escola era a igreja, né? Com a escola em construção, ia ter o alojamento do professor, entendeu, mas quando eu saí de lá, ainda estava em construção a escola. [...] Entendeu? Então, eles me abrigaram lá, eles me abrigaram. Aí quando eu vinha, eu preparava uma feirinha, alguma coisa pra levar, pra ajudar no mantimento lá. Na casa da minha aluna, a merendeira da escola, que era onde eu fiquei enquanto fiquei lá. (Lírio)

Destacam-se também os relatos de Margarida e Alfazema, que descrevem suas primeiras experiências na regência em classes de escolas privadas. Nestes casos, os depoimentos não fazem menção às questões que envolvem dificuldades estruturais ou ao desafio apresentado à heterogeneidade das classes. Sugere-se, desta forma, que o ingresso em classes da rede pública estadual oferece, ao professor iniciante, vivências diferentes daquelas ofertadas ao principiante que ingressa em classes da rede privada, devido às próprias peculiaridades dessas redes (PORTELLA e LELIS, 2014).

Eu fui pra uma escola particular, por necessidade mesmo, eu ainda nem havia terminado, eu estava terminando, eu acho que eu estava no sétimo ou oitavo período, no finalzinho do curso. E lá, nessa escola particular, como eu já tinha experiência como auxiliar na fundação, eles não... não era uma exigência que a pessoa estivesse formada, e eu acabei dando aula lá um ano para uma turma de segundo ano [...] Ai, era uma turminha pequena, que era uma escola particular não muito visada. Eu acho que eu tinha em torno de 10, 12 alunos, eu acho [...] Foi a minha primeira experiência assim, com minha turma, foi lá, nessa escolinha particular. [...] Com a turma, com os alunos, foi tudo tranquilo, eram tranquilos. Assim, questão de desafios com a turma, não, acho que não. (Margarida)

Então, eu fui pro [nome do colégio privado], assumi uma turma lá que já tinha começado junto, estava pertinho do primeiro bimestre, de fazer o primeiro bimestre. Eu fiquei com essa turma e, no final do ano, o meu contrato foi renovado pra 2015. Fiquei com o $5^{\circ}$ ano em 2014 e 2015. [...] O impacto foi assim... Que quando eu comecei no [nome do colégio privado], tu chegava, tu dava a tua aula, e tu terminava, tu ia embora. Quando eu conversei com a coordenadora, ela me disse: "Não, aqui você não é tia, aqui você é professora" A postura da coordenadora da escola, da época, era o quê? “Aqui quem tem vez é o professor, não é o aluno”. [...] Em 2014, eram uns 26 alunos. E assim, eles eram muito agitados, muito agitados, assim. Eram super inteligentes! Mas... já estavam naquela fase de começar a namorar, sabe? (Alfazema)

Reforça-se que, ao se comparar os relatos dos sujeitos que iniciaram o exercício do magistério na rede pública e aqueles que debutaram na rede privada, a distinção entre o 
desenvolvimento da aprendizagem dos alunos é marcante, sendo mais ressaltadas as dificuldades apresentadas pelos alunos das escolas públicas. Entretanto, todos os sujeitos sugerem, a partir de seus relatos, que as exigências iniciais para desempenhar a docência se concentram na prática do ofício na sala de aula - sendo esta ainda sem fontes de aquisição consolidadas (TARDIF e RAYMOND, 2000), uma vez que os sujeitos de pesquisa eram inexperientes na regência.

As indicações dos entrevistados reforçam não apenas sua inexperiência, como também as questões que envolvem a rotina escolar do professor, bem como suas repercussões nas vivências dos professores iniciantes, que após a apresentação das características e saberes demandados para a condução de suas primeiras classes, os sujeitos foram estimulados a rememorar os primeiros momentos de suas trajetórias nas escolas em que iniciaram a docência como professores regentes. Ao identificarem o modo como foram acolhidos nas primeiras instituições e a forma como iniciaram suas atividades docentes, eles descreveram lembranças fundamentais para caracterizar o papel dos saberes docentes nestas vivências iniciais da socialização profissional.

Neste ponto, é interessante ressaltar como duas entrevistadas, Dália e Rosa, recordam-se do desinteresse e das imposições da gestão nos primeiros momentos que ingressaram na escola aceitas por elas sem quaisquer discussões. É perceptível que os professores iniciantes sentem-se essencialmente distantes das esferas de poder da escola e, com isso, não se sentem autorizados a verbalizar suas opiniões, aceitando as ações da gestão sem questionamentos (KNOBLAUCH, 2008). O depoimento de Dália retrata bem esta realidade.

A diretora só, só ela que me recebeu. Ela me pegou, foi lá, me mostrou a sala que eu ia ficar, falou o horário, mas... foi só isso mesmo. Ela falou assim: "Segunda-feira, você vem trabalhar, você começa", aí... sinceramente, eu era muito verde, não sabia de nada, meu Deus do céu!, Se for lembrar assim, eu não sabia. Não tinha material também. [...] Eu acho que bem recebida seria se ela dissesse: "Olhe, essa aqui é a rotina, os meninos estão estudando isso, tem livro aqui, você pegue, pesquise isso, isso e isso, está aqui o material”, mas não, não foi nada disso.

(Dália)

Em diálogo ao apontamento apresentado por Dália, que indica como uma escola deve receber bem uma docente, Rosa fez indicações de como uma instituição é capaz de acolher, de maneira tranquila, uma professora iniciante. O relato de Rosa, apresentado a seguir, reflete a sua própria recepção na primeira escola em que atuou como regente de classe. Neste depoimento, Rosa apresenta um "rito de passagem" feliz, apesar dos conflitos que permearam sua saída da posição de estudante para o reconhecimento de sua condição profissional (EDDY, 1971 apud TARDIF, 2002), o que principiou bem durante sua formatura. 
Na primeira escola, eu fui recebida muito bem, muito bem mesmo assim; e eu estava ainda me formando, começando tudo... Então assim, eu entrei na semana de atividades de comemorações, entendeu? Era aula da saudade, a minha colação de grau, a minha festa, tudo lindo... Então, entrei nessa semana, e aí... assim, a gestora, ela foi superbacana comigo, entendeu, me ajudou a ajustar os meus horários pra que eu pudesse estar participando das comemorações, da formatura mesmo, entendeu? Recebi todo o apoio dela, da coordenadora, em relação à turma... E ia ser a minha primeira turma... [...] Foi muito legal assim, foi uma equipe assim, nota 10; de vez em quando, eu vou lá matar a saudade do pessoal porque foi muito bom! (Rosa)

É significante observar o entusiasmo inicial e a satisfação de Rosa ao receber sua primeira turma, vivendo seus primeiros momentos descoberta como docente (HUBERMAN, 1992) ao ser recebida na primeira em que lecionou. Entretanto, não é essa a mesma reação por ela apresentada ao descrever suas vivências na segunda escola em que leciona. O relato a seguir explicita um dos momentos em que Rosa questionou sua visão idealista diante da profissão (VEENMAN, 1984).

Faz-se importante ressaltar também que, na primeira escola em que trabalhou, Rosa atuou como professora temporária (contratada por um período provisório de dois anos); já na segunda escola, Rosa assumiu a condição de docente efetiva (concursada). Apesar de atuar como professora temporária, Rosa sentiu-se muito mais partícipe das questões escolares na condição de professora temporária na primeira escola em que lecionou, por quatro meses, apesar do desafio em receber uma turma com alunos que aparentavam ter dificuldades de aprendizagem. Na segunda escola, em que atuou como professora efetiva, também por quatro meses, a recepção (ou a ausência desta) é transmitida como um sinal de decepção no relato de Rosa.

Já na segunda escola não foi muito bom, porque eu entrei no lugar de uma professora que eles gostavam muito, que era provisória, infelizmente, então assim, tiraram ela pra colocar uma efetiva, então... Eu fui recebida assim... colocaram uma barreira, né? [...] Então, no primeiro dia que eu cheguei, já pra dar aula, a diretora ainda não estava na escola, né, então, eu cheguei, já tinha dado o horário, os alunos estavam dentro de sala, eu cheguei, entrei pra sala de aula, e aí eu estava lá já me apresentando pros alunos, explicando a situação, e a coordenadora chegou, bateu na porta! Aí... aí perguntou quem eu era e tal, aí eu falei que eu tinha me apresentado na sexta-feira, tinha conversado com a diretora, e que eu era a nova professora, e como eu cheguei, perguntei, não tinha ninguém, entrei pra sala e fui dar a minha aula. Aí ela ficou meio assim, né, e tal. (Rosa)

As distintas caracterizações feitas por Rosa, quanto ao ingresso nas duas escolas em que lecionou, se relacionam à forma como o núcleo gestor recebeu a professora iniciante. Dessa forma, como bem coloca Mizukami et al. (2002), percebe-se como é importante que o professor se sinta 
parte da escola em que trabalha, recebendo apoio e assessoria da direção da instituição em que leciona.

Com vivências nas escolas privadas, Margarida e Alfazema também destacaram o papel das diretoras de suas escolas ao recebê-las para os primeiros dias de trabalho. Margarida afirmou: "a diretora da escola pegou meu currículo e decidiu que tava bom, que dava, que eu dava conta de trabalhar lá". Já Alfazema indicou que mesmo sendo "muito delicada e ponderada, era ela [a diretora] quem resolvia quem ficaria e onde ficaria" e, ainda, complementa: "no início, quando ela dizia 'vamos conversar?' eu ficava assustada!’. É importante ressaltar que, como bem coloca Knoblauch (2008), no início da socialização profissional, o jovem professor já é capaz de ter a figura dos gestores escolares como superiores e fazer "o reconhecimento da hierarquia como algo legítimo" (p. 129).

Os estudos de Knoblauch também auxiliam na interpretação do papel da coordenação escolar, tanto no primeiro momento de ingresso na nova escola quanto no desenvolvimento das atividades docentes. De acordo com a autora, este momento de partilha é fundamental para o bom caminhar das atividades docentes.

No presente estudo, o momento de planejamento, com o auxílio da coordenação pedagógica, é visto de maneira distinta pelas entrevistadas, o que pode ser explicado pelos diferentes profissionais e relações de convívio partilhadas pelos sujeitos de pesquisa não apenas com os profissionais da coordenação pedagógica, como também com os demais professores.

Rosa traz novamente um paralelo entre as duas escolas que lecionou, demonstrando experiências muito distintas de uma escola para outra. É fundamental ressaltar também que ela menciona, no depoimento a seguir, a importância de uma professora que muito a auxiliou no princípio da docência. Este dado é significante, pois apenas Rosa menciona o apoio de uma colega de trabalho para a superação de suas dificuldades iniciais na docência, diferentemente dos demais entrevistados que não fazem qualquer indicação semelhante.

Então assim, às vezes eu acho que elas [coordenadora e diretora] até ficavam preocupadas, com medo de eu não conseguir, porque era minha primeira turma mesmo. Mas, elas estavam lá me auxiliando em tudo que eu precisava. A outra professora também, que era a professora inicial da turma maior de alfabetização. Aquela que ficou com a turma melhor, sabe? Ela foi muito bacana comigo porque tinha muita coisa que eu não sabia e ela me ajudou. Eu tenho contato até hoje com ela assim; me auxiliou muito, assim, me ajudava, nós planejávamos juntas, né? Porque todos os professores do primeiro ano, tanto do turno da manhã, como do turno da tarde, planejavam juntos com a coordenadora. [...] Agora... Assim, o planejamento também era mais complicado nessa segunda escola, porque era um planejamento que era feito

Revista Teias v. 18, n. 50, 2017 (Jul./Set.): Conversas sobre formação de professores, práticas e currículos 
pela coordenadora, entendeu, então assim, só chegava, estava feito, me entregava. E... é... não gosto muito disso, não; tipo assim, é bom porque fica 10 minutinhos lá, na sala, e vai embora, né. Em questão de tempo, de você ir pra casa mais rápido, mas ela não conhecia a realidade da minha sala, né, então, não sabia o que a minha sala precisava. Às vezes vinha um planejamento assim, repetido de coisas que eu já tinha realizado, e estava ali pra eu realizar, então, eram dois trabalhos, ela me dava, e eu modificava tudo porque não cabia aquilo que estava posto ali, né? Aí eu tinha que estudar, procurar e fazer algo que tinha mais a ver com os meus alunos, né? (Rosa)

Em diálogo com as vivências que Rosa trouxe da segunda escola em que lecionou, Dália também se queixou das fragilidades do planejamento, indicando-o como ausente nos primeiros meses em que começou a lecionar - mas acreditando que este seria absolutamente necessário.

Eu ia à tarde, só tinha um primeirinho à tarde, e a minha coordenadora do primeiro ia de manhã... era um primeiro ano à tarde, e o resto tudo era de manhã, os outros primeiros anos e os segundos anos. E aí a coordenadora só ia de manhã. À tarde era o terceiro ano e o quarto. Então, eu ficava sem coordenadora, e sem... ela não dava pra planejar comigo porque ela planejava outro horário, eu não sei o porquê [...] Aí tinha uma rotina lá que ela deixava pra mim, mas eu não sabia o que é que era; E ela me dava só aquela rotina; não chegava atividade junto. Aliás, pra mim, nem nada chegava. E eu tinha que me virar nos 30. Eu até brinco com as meninas que, na rotina, vem atividade pra ANA, que se chama ANA as crianças que não sabem ler, e os Alfas, os alfabéticos. Eu nem sabia nada, nem do que eram aquelas siglas. Aí eu pegava a rotina, aí alfabeto móvel, essas coisas... Era bem difícil aí sem, como a gente não tinha esse planejamento, na semana, e eles só cobravam, cobravam, cobravam. Aí tive que me virar nos 30 mesmo, tive que pedir ajuda pra colega, ir pra livro, ir pra internet, pra essas coisas... (Dália).

É significante ressaltar que Rosa e Dália tiveram expectativas semelhantes quanto à partilha dos saberes da experiência, oriundos da socialização profissional, considerando estes como fundamentais ao bom envolvimento e ao prosseguimento de suas atividades docentes. Carentes do auxílio de seus pares mais experientes e dos melindres da profissão, elas aparentam que procuraram compensar sua inexperiência com a busca de saberes oriundos dos possíveis materiais de trabalho, das "ferramentas" mais utilizáveis em seu trabalho (TARDIF e RAYMOND, 2000, TARDIF, 2002). Com isso, elas aparentaram certa tranquilidade para dar prosseguimento às atividades mais comuns em suas rotinas.

Entretanto, é possível sugerir também que a busca de mais instrumentos de trabalho acontece também para o fortalecimento dos saberes da experiência. Ou seja: os instrumentos de trabalho (tais como programas, livros didáticos, diretrizes, regras do estabelecimento entre outros) para a composição do planejamento são adaptados gradativamente pelo professor iniciante, que 
busca ferramentas diversificadas de trabalho enquanto consolida sua experiência (TARDIF e RAYMOND, 2000).

É significativo observar que as entrevistadas que tiveram suas primeiras experiências na rede privada não fazem menção ao planejamento como um momento importante. Diante do relato de Margarida - e de suas vivências em uma escola privada e em uma instituição pública - sugere-se que o material didático orientado e de uso obrigatório (em apostila), muito comum na rede particular, esse momento seja menos frequente que o programado para a rede pública.

$\mathrm{Na}$ escola particular, a gente tinha que seguir o material apostilado, ela [diretora - que era também coordenadora e proprietária da escola] não planejava com a gente, não. Mas... os planejamentos, da escola do Estado. Lá, nós planejávamos até demais, a gente até reclamava que era planejamento demais. A gente tinha o planejamento individual, individual assim, que era a coordenadora pedagógica. Tinha com os outros dois professores... todos os professores do segundo; esse era separado do planejamento da coordenadora. (Margarida)

Mesmo com uma vivência distinta, em uma escola no meio rural, Lírio também faz relatos sobre seus momentos de planejamento, apesar das situações adversas impostas pelas condições da escola no meio rural.

Eu tinha o meu planejamento, eu anotava tudo no meu... meu caderno, os meus conteúdos, as minhas aulas, a forma como que eu ia ministrar a aula, e no período da manhã, eu me preparava nesse sentido. Lá, na casa onde eu ficava, eu ficava sozinho, né, a merendeira ia pra escola e eu podia ficar lá sozinho. Era até bom, porque eu dava uma olhada melhor nos livros que eu tinha levado e tal [...] Quando eu precisava de ajuda, ajuda mesmo, e eu ia para Rio Branco, pra zona urbana, eu pedia ajuda, algumas partes das vezes, da minha tia, professora, que, na época, ela era coordenadora também... (Lírio).

Esses depoimentos pressupõem que as influências da gestão e da coordenação escolar - bem como o trabalho dos profissionais que ocupam estas lideranças - leva o professor a formar/reformar sua identidade docente. É preciso salientar também que, durante toda a trajetória profissional do docente, a construção dos primeiros “degraus" de sua identidade como professor, está profundamente relacionada aos processos de socialização incididos no espaço escolar do qual este docente faz parte na sua iniciação no magistério. Além disso, é preciso reconhecer como a imprevisibilidade da experiência, conhecida e reconhecida com o passar do tempo faz com que cada indivíduo consolide uma "identidade para si" e uma "identidade para os outros" (CARROLO, 1997). 


\section{CONSIDERAÇÕES FINAIS}

Ao se retomar o objetivo central da pesquisa, em identificar aspectos marcantes do princípio do exercício profissional vivenciado por professores iniciantes, percebe-se a pluralidade de memórias e experiências demandadas pelos sujeitos desta pesquisa ao principiarem em suas atividades profissionais.

Ao relatarem as cenas que refletem o ingresso na escola que os recebeu como iniciantes, os sujeitos geralmente demarcam a figura hierárquica da diretoria e o respeito a ela submetido. Uma recepção acolhedora na escola é indicada como uma condição importante para a realização de um trabalho satisfatório nas primeiras classes. Reforçando o vínculo entre o processo de socialização profissional dos professores na escola e a construção dos saberes da experiência, alguns sujeitos citam o convívio entre os pares, especialmente no momento de planejamento pedagógico, como fundamental às primeiras práticas em sala de aula, ao destacarem também que certos artifícios de ensino são aprendidos somente no ofício da docência.

Os referidos achados da pesquisa reforçam a crença de que a longa trajetória de socialização profissional, ainda a ser vivenciada por um professor iniciante, merece ser considerada em consonância com sua identidade como docente, baseada em pilares construídos (e em construção) por este profissional desde os momentos iniciais de sua carreira. Logo, é fundamental que mais estudos sobre esta temática sejam apresentados, acreditando-se na importância em se prosseguir na busca por algumas respostas às perguntas que permeiam a inserção destes profissionais no ambiente da escola. É preciso (re)conhecer: como os acolher de modo que se sintam seguros? Como auxiliálos a articular teoria e prática sem o prejuízo de nenhuma delas? Como apoiá-los na articulação dos saberes que já produziram e nos tantos outros que ainda produzirão? Como fazer com que se sintam satisfeitos ao assumirem sua identidade docente como carreira a ser consolidada? Como fazer para que eles vejam mais motivos para permanecer/retomar a profissão do que para abandoná-la?

São estas questões que guiarão mais trabalhos e descobertas sobre os professores iniciantes e, especialmente, sobre um melhor caminho que pode leva-los à consolidação da carreira no magistério no estado do Acre e em todo Brasil. 


\section{REFERÊNCIAS}

ALMEIDA, P.C.A.; BIAJONE, J. Saberes docentes e formação inicial de professores: implicações e desafios para as propostas de formação. Educação e Pesquisa, São Paulo, v.33, n.2, p.281-295, 2007. Disp.: <http://www.unaerp.br/ revista-cientifica-integrada/edicoes-nteriores/edicao-n-2-2014-1/1464-161-454-1-sm/file>. Acesso em: 21 fev. 2016.

CARROLO, C. Formação e identidade profissional dos professores. In: ESTRELA, M. T. (Org.) Viver e construir a profissão docente. Porto: Porto Editora, Coleção Ciências da Educação, n. 26, 1997, p. 21-50.

DUBAR, C. A construção de si pela atividade de trabalho: a socialização profissional. Cadernos de Pesquisa. São Paulo, v. 42, n. 146, p. 351-367, 2012. Disp.: 〈http://www.scielo.br/pdf/cp/v42n146/03.pdf>. Acesso em: 01 nov. 2015.

DUBAR, C. A socialização: construção das identidades sociais e profissionais. São Paulo: Martins Fontes, 2005.

DUBAR, C. La socialisation: construction des identités sociales et professionnelles. Paris: Armand Collin, 1992.

EDDY, E. Becoming a Teacher: The Passage to Professional Status. New York: Columbia University Techers Colege Press, 1971.

HUBERMAN, M. O ciclo de vida profissional dos professores. In: NÓVOA, A. (Org.). Vidas de professores. Porto: Porto Editora, 1992. p. 31-61.

JANATA, N.E.; ANHAIA, E.M. Escolas/Classes Multisseriadas do Campo: reflexões para a formação docente. Educação e Realidade, Porto Alegre, v. 40, n. 3, p. 685-704, 2015. Disp.: <http://www.scielo.br/scielo.php? script=sci_arttext\&pid=S2175-62362015000300685\&lng=en\&nrm=iso>. Acesso em: 27 abr. 2016.

KNOBLAUCH, A. Aprendendo a ser professora: um estudo sobre a socialização profissional de professoras iniciantes no município de Curitiba. Tese (Doutorado em Educação: História, Política, Sociedade) - Pontifícia Universidade Católica de São Paulo. São Paulo, 2008, 176fl. Disp.: <http://www.dominiopublico.gov.br/ pesquisa/DetalheObraForm.do?select_action=\&co_obra=105545>. Acesso em: 05 abr. 2016.

LIMA, V.M.M. Formação do professor polivalente e os saberes docentes: um estudo a partir de escolas públicas. 2007. Tese (Doutorado em Educação) - Universidade de São Paulo, São Paulo, 2007. Disp.: <http://www.teses. usp.br/teses/disponiveis/48/48134/tde-12032009-111920/pt-br.php>. Acesso em 08 dez. 2015.

MARCELO GARCÍA, C. Formação de Professores: para uma mudança educativa. Porto: Porto Editora, 1999.

MINAYO, M.C.S. O desafio do conhecimento: pesquisa qualitativa em saúde. 13. ed. São Paulo: Hucitec, 2013.

. Pesquisa Social: teoria, método e criatividade. Petrópolis: Vozes, 2002, p. 16-18.

MIZUKAMI, M.G.N. et al. Escola e aprendizagem da docência: processos de investigação e formação. São Carlos: EdUFSCar, 2002.

NÓVOA, A. Formação de professores e profissão docente. In: NÓVOA, A. Os professores e sua formação. Lisboa: D. Quixote, 1992. Disp.: http://repositorio.ul.pt/bitstream/10451/4758/1/FPPD_A_Novoa.pdf. Acesso em: 25 abr. 2017.

NÓVOA, A. O passado e o presente dos professores. In: NÓVOA, A. (Org.). Profissão Professor. Porto: Porto Editora, 1991. p. 13-34.

PORTELLA, V.C.M.; LELIS, I.A.O.M. Professores Iniciantes: inserção em diferentes redes de ensino. In: XVII Endipe. Fortaleza. Anais..., 2014. Disp.m: <http://www.uece.br/endipe2014/ebooks/livro2>. Acesso em: 30 mai. 2016.

TARDIF, M. RAYMOND, D. Saberes, tempo e aprendizagem do trabalho no magistério. Educação e Sociedade, Campinas, v.21, n.73, p. 209-244, dez. 2000. Disponível em: < http://ltc-ead.nutes.ufrj.br/constructor/objetos/ saberes,\%20tardif.pdf > Acesso em: 05 dez. 2014.

Saberes docentes e formação profissional. 2. ed. Petrópolis: Vozes, 2002.

TERUYA, T.K. et al. Classes multisseriadas no Acre. Revista Brasileira de Estudos Pedagógicos, Brasília, v.94, n.237, p.564-584, 2013. Disp.: 〈http://www.scielo.br/pdf/rbeped/v94n237/a11v94n237.pdf>. Acesso em: 30 mai. 2016.

VEENMAN, S. Perceived problems of beginning teachers. Review of Educational Research, n. 54, v. 2 , 1984.

Revista Teias v. 18, n. 50, 2017 (Jul./Set.): Conversas sobre formação de professores, práticas e currículos 


\section{RESUMO}

Objetivou-se identificar aspectos marcantes do princípio do exercício profissional vivenciado por professores iniciantes, considerando a importância desta fase na formação da identidade docente. Para tanto, entrevistouse cinco professores iniciantes que principiaram suas atividades como unidocentes em classes do ensino fundamental no município de Rio Branco, estado do Acre. Constatou-se que os sujeitos de pesquisa vivenciaram trajetórias distintas, mas são unânimes em afirmar que a recepção das equipes escolares, nas primeiras instituições em que lecionaram, foram fundamentais para a sensação de segurança (ou insegurança) concebida nas atividades iniciais. Reconhece-se que a consolidação da identidade docente está associada ao apoio que o professor iniciante recebe suas primeiras ações.

Palavras-chave: Professores Iniciantes. Socialização Profissional. Identidade Docente.

\section{THE BEGINNING OF THE PROFESSION: AN IMPORTANT STEP IN THE FORMATION OF TEACHER PROFESSIONAL IDENTITY}

\section{ABSTRACT}

The research aimed to identify important aspects of the beginning of the professional exercise of beginning teachers, considering the importance of this period for the formation of the teaching professional identity. Thus, we interviewed five beginning teachers who began their profession as teachers in elementary school classes in the city of Rio Branco, in the state of Acre. Interviewees had different trajectories, but all said that the way school staff received them in the very first schools they worked on was very important for them to feel secure (or insecure) in their early activities as teachers. It is recognizable that the construction of the teacher professional identity is associated with the support that the beginning teacher receives his first school actions.

Keywords: Beginners Teachers. Professional Socialization. Teaching Professional Identity.

\section{EL PRINCIPIO DEL EJERCICIO PROFESIONAL: UN IMPORTANTE PASO EN LA FORMACIÓN DE LA IDENTIDAD PROFESIONAL DOCENTE \\ RESUMEN}

La investigación objetivó identificar aspectos marcantes del inicio del ejercicio profesional de profesores principiantes, considerando la importancia de este período para la formación de la identidad profesional docente. Así, fueron entrevistados cinco profesores principiantes que iniciaron en la profesión como profesores regentes en clases de la enseñanza fundamental en la ciudad de Rio Branco, en el estado de Acre. Los entrevistados tuvieron trayectorias diferentes, más todos afirmaron que la forma en que los equipos escolares los recibieron, en las primeras escuelas en que trabajaron, fueron muy importantes para sentirse seguros (o inseguros) en sus primeras actividades como profesores. Es reconocible que la construcción de la identidad profesional docente se asocia al apoyo que el profesor principiante recibe sus primeras acciones escolares.

Palabras clave: Profesores Principiantes. Socialización Profesional. Identidad Profesional Docente.

Submetido em Dez./2016

Aceito em Mai./ 2017

Revista Teias v. 18, n. 50, 2017 (Jul./Set.): Conversas sobre formação de professores, práticas e currículos 